\title{
THE INFLUENCE OF JEOPARDY GAME TOWARDS STUDENTS' VOCABULARY MASTERY
}

\author{
Novilisa, Sunara, Sumpena Rohaendi \\ Pendidikan Bahasa Inggris, FKIP, Universitas Subang \\ Novi.lisa15@gmail.com, Rasunaok@gmail.com, \\ Sumpenarohaendi07786@gmail.com,
}

\begin{abstract}
This research is motivated by the students get difficulties in using the English vocabulary and students needed interesting technique when they learnt English. One of learning techniques that can help students understand about the material is jeopardy game. The purposes of this study are to know Jeopardy Game is influence on the students' vocabulary mastery and the response of the students' the learning use Jeopardy game on vocabulary mastery. This research used a quasi-experimental and the research design used is the non-equivalent pre-test post-test control group design. The Research was conducted in SMPN 1 Dawuan. The sample are VIII-A as control class and VIII-B as experiment class. The research instrument that used are test and questionnaire. The result of the research shows; the students' response to learning by using jeopardy game got a very good category with an average was $65.85 \%$ and there is a significant influence between jeopardy game of learning towards students' vocabulary mastery was $2.4 \%$ while the remaining $77.6 \%$ is influenced by other factors. Based on the findings, it can be concluded that the application of jeopardy game can not the influence students' vocabulary mastery. Especially at the first grade student of SMP Negri 1 Dawuan in academic year 2018/2019.
\end{abstract}

Keywords : Jeopardy Game, Vocabulary Mastery.

\section{BACKGROUND}

English as International language is spoken almost all over the world and is one of the most important things in communication and is used as a means of getting information between people throughout the world. In the global era, English takes an important role as communication language used in many sector of life, such as trading, bilateral relationship, politic, science, technology and many others. In fact, people use the language to express their feelings, ideas, and desires. English has become the language used by many people over the world to connect and share with another. Therefore, people should understand and master English in order to gain broader knowledge, information and technology.

Vocabulary is one of skills that must be taught by students to learn English, because vocabulary has an important role to expand language skills. In other words, 
the first thing that has to be mastered by language learners in learning is vocabulary. It can says that vocabulary is the words that compose a language. Teaching vocabulary is not easy. Teacher should find the best or the effective technique to teach English vocabulary. Sadiman (2008) In general, "Many teachers teach vocabulary based on handbook without using other media. Indirectly", it makes the students bored and also lazy to learn the new word. Low vocabulary make students have difficulty to mastery English in speaking, reading and writing. Then, vocabulary is very important in learning one of language. However, to mastery language needs vocabulary. Students need one technique to learn. So that, to solve the problem, the research will try to apply jeopardy game in order to make them interest in learning Vocabulary mastery.

Based on observations made at SMPN 1 Dawuan there found several problems related to the vocabulary learning process. Students needed interesting technique when they learnt English, students were lazy to open their dictionary, Students get difficulties when they are given the task of text. Students get difficulties in using the English vocabulary in the sentence, Students get difficulties in understanding the form of word or vocabulary such as noun, verb, adjective, and pronoun.

Based on the description problem above, to solve the problems and increase vocabulary mastery in SMPN 1 Dawuan, the research should consider the most effective teaching strategies and creative enhance students in vocabulary mastery . It was recognized that the right strategy in order to motivate students to vocabulary mastery. The research proposes one technique, the technique is named jeopardy game. Classroom Jeopardy is Based on the American television game show jeopardy. It is a version of jeopardy made especially for classroom. The show has a unique question-and-answer in which contestants are presented with clues in the form of answers, and must phrase their responses in question form. It can be conclude that jeopardy game is a game where the question in form of answer like description and the answer is form of question and it is a quiz where made in to learning activity in the classroom.

When learning vocabulary mastery in the classroom with game they not fell bored because they fell, that they are playing a game. On learning vocabulary mastery using jeopardy game, the teacher will discuss every question clearly. Until the students become motivated to learn English.

The previous research with Jeopardy Game was conducted by Sari (2015), “The Effectiveness of Using Jeopardy Game Towards Student's Achievement in Simple Present Tense at The Eighth Grade of MTsN Langkapan Srengat". It can be concluded that Jeopardy is an effective technique that can be used in simple present tense teaching for junior high school students. In relation to this, the researcher was interested in conducting a study which was focused on "The Influence of Jeopardy 
Game Towards Students' Vocabulary Mastery" at Seventh Grade of SMPN 1 Dawuan in Academic Year of 2018/2019. The formulation of problem in this research are as follows : (1) Is there any influence of jeopardy game towards students vocabulary mastery? (2) 2 . How is students response in learning process by using jeopardy game?

\section{THEORETICAL DESCRIPTION} The Definition of Vocabulary

Vocabulary have certainly found in every aspect of language. The importance of vocabulary can influence learning activity. Vocabulary can help learner to express their ideas and information. Without vocabulary, learner cannot understand about the information that they learnt. In other words, learner should have large vocabulary in order to do well for their competencies.

Vocabulary is part of the language system. In addition, the quality of learners' vocabulary influences the four language skills. Richards and Renandya (2002: 255) proposed that "vocabulary is an important part of language proficiency and grant much of the basis for how well learners listen, speak, read, and write". He said that learners can achieve less than their potential without an extensive vocabulary and strategies for acquiring new words.

\section{The Types of Vocabulary}

According John (2000) divided vocabulary become two kinds:

a. function words. These words can be seen in grammatical aspects, such as articles, prepositions, pronouns, conjunctions, auxiliaries.

b. content words. These words modify the meaning and provide links to the sentences. The kinds of these words are noun, verb, adjective, and adverb.

Gairns and Redman (2014) define vocabulary to receptive and productive vocabulary.

a. Receptive vocabulary is the language items which can be recognized and comprehended in the context of reading and listening material.

b. Productive vocabulary is language items which the learner can recall and use appropriately in speech and writing.

\section{Game}

Game is an activity which is entertaining and engaging, often challenging, and an activity in which the learners play and usually interact with others.

According to Wright (2006) "game is an activity with rues, a goal and an element of fun". It can be concluded that games is the activity that can make people 
communicate with other especially in the classroom. In the classroom, games build studentse relationship between their friends because games will make they have challenge with others.

\section{Jeopardy Game}

Several games taking the form of the popular television game show, Jeopardy, have been developed and used in the classroom to tech different areas, such as business and health sciences.

Ernest (2012) Jeopardy game is an American quiz show that features topic such as history, literature, the arts, pop culture, science and sports. The show has a unique question-and-answer format in which contestants are presented with clues in the form of answers, and must phrase their responses in question form.

Although some creative games can be used for teaching vocabulary in this study, the researcher will choose Jeopardy game. Jeopardy game is adopted from television quiz show and adopted into language game for educational tool by Friedman (2001). The writer chooses this game because Jeopardy can make students become motivated to have the high score.

From the explanation above, the research can be concluded that jeopardy game is a game that has been adopted from television quiz and has a unique design where the question is in answer form and the answer must be question form.

\section{The Use of Jeopardy Game in Teaching Vocabulary}

According to Bee and Hayes (2005), Teaching vocabulary by using Jeopardy games is very interesting because students will be active and interested in this activity. Before the game started, the teacher must be design the game. The teacher have to make some categories and point. Jeopardy uses LCD and power point presentation. There are the procedure of using jeopardy game :

a. The teacher divided students into 6 groups, each group included 5 students.

b. The teacher shows the slides on power point. The first slide includes 4 topics and 5 scores (100-500) and there are the questions or clue behind the question mark.

c. After the preparation finished, the teacher commands students for the first group who can quickly put their hands.

d. The group can choose one topic with one score they want. For example, group 2 choose „Body, Face, and Hair" topic with 200 score.

e. If the group can answer the question, score 200 is for them.

f. The students cannot use the dictionary but they can ask their member of group about what is the answer. 
g. If the group cannot answer the question, the teacher will choose other group who put hands up quickly.

h. The group who get the highest score is the winner.

i. This game is ongoing for about 40 minutes.

j. After all questions are answered, the teacher and students discuss it together.

It can be concluded that Jeopardy game means a game of jeopardy. Teaching vocabulary by using Jeopardy games is very interesting because students will be active and interested in this activity.

\section{RESEARCH METHODOLOGY}

This research is an experiment research and the writer used quasi experiment as the design. There are two different groups of treatment in experiment research, namely experiment and control group. In experiment group the students were taught by using jeopardy game, while in control group the students were taught without using jeopardy game. Both groups were given pre-test and post-test. Pretest was given in the first meeting and in the end of the meeting, the researcher gave post-test. It was treated after the process of class treatment.

Technique of data collection in this research were test (pretest-posttest), questionnaire and observation. Technique of data analysis used quantitative and qualitative data analysis. The test was done by using SPSS Version 17.

\section{THE RESULT OF RESEARCH}

Quantitative Data Analysis

In normality test, the significant value obtained pretest of experiment and control class were higher than 0.05 . It can be concludes that both experiment and control class in the pretest had normal distribution. Further, The significant value obtained posttest of experiment and control class were higher than 0.05. It can be conclude that both of experiment and control class had normal distribution. Pretest and posttest had normal distribution.

The result of homogeneity test between experiment and control class in pretest and posttest was higher than significance $\alpha 0.05$. It means that scores between experiment and control class in pretest and posttest were homogeneous.

The value sig. (2-tailed) in pretest was higher than 0.05 . Then, there was not difference of means between experiment and control class in pretest. Furthermore, the value sig. (2-tailed) in posttest was higher than 0.05 . Then, there was not difference of means between experiment and control class in posttest.

Based on the model summary in simple linear regression test, R square was 0.024 with significance 0.924 . It means that the influence which was can explained of independent variable (questionnaire) towards dependent variable (posttest) was 
2.4\%. While, $97.6 \%$ influenced by other variables. Standard error of the estimate was 15.916 and standard deviation was 5.272. Standard error of the estimate was higher than standard deviation, then model of regressing is not good enough as predictors. Based on the coefficient, constant of 58.088. If there is nothing questionnaire, then value of posttest is 58.088. Regression coefficients $\mathrm{X}$ of 0.054 , it means each addition 1 value of questionnaire then decline of posttest value of 0.054 .

Based on the result of simple linear regression, there was not the significant influence of Jeopardy Game towards students' vocabulary mastery.

Qualitative Data Analysis

There are five indicator in questionnaire. First, the result of students' interest in learning English was $74.37 \%$. Second, students' response to english learning was $55.16 \%$. Third, students' interest in learn English by using jeopardy game was $74.16 \%$. Fourth, students' ability to understand the material by using jeopardy game was $62.50 \%$, and students'response to jeopardy technique was $63.09 \%$. The questionnaire precentage means was $65.85 \%$ and include as very good category. Thus, students' response towards jeopardy game technique classified as very good.

\section{CONCLUSION}

Based on the research conducted in SMPN 1 Dawuan, it can be concluded that that there was not the significant influence of jeopardy game technique towards students'vocabulary mastery. Based on the result of model summary in simple linear regression, there was only $2.4 \%$ of the influnce which can explained and $97.6 \%$ influenced by other variable. Meanwhile, students response towards jeopardy game technique in class VII B in SMPN 1 Dawuan classified as very good category.

\section{REFFERENCE}

Bee and Hayes.(2005.) Hayes, Using Jeopardy Game to enhance Student Understanding of Accounting Information System (AIS) exam Material, Vol. IX No. 1.

Gairns and Redman (2014) Working with Words. A guide to teaching and learning vocabulary, (Cmbridge University Press), p. 73-75.

Harry, F. (2011). Classroom Jeopardy: Teachers' Guide, (USA: Jeopardy Production), p. iii.

Jhon (1984). An Introduction to English Language Teaching. Singapore: Longman Grorup,Ltd. Read, John. Assessing Vocabulary. Cambridge University Press, 2000.

Richards. J and Renandya. W(2002) Methodology in Language \Teaching, An Anthology of Current Pactice. NewYork: Cambridge University Press. 
Sadiman, A. (2008). Media Pendidikan. Jakarta: PT. Raja Grafindo.

Sari, A.F. ( 2015). "The Effectiveness of Using Jeopardy Game Towards Student's Achievement in Simple Present Tense at The Eighth Grade of MTsN Langkapan Srengat”. Thesis. English Education Program. State Islamic Institute (IAIN) of Tulungagung.Tidak di terbitkan.

Wright, A. (2006) Games for Language Learning. New York: Cambridge Universiry Press. 